\title{
CLINICAL STUDY ON THE PRE-OPERATIVE HEARING IN THE RADICAL MASTOID OPERATION
}

\author{
By \\ T. MATSUOKA \\ From the Department of Oto-Rhino-Laryngology, Faculty of Medicine, \\ Univ?rsity of Tokyo. (Director: Prof. I. Kirikae)
}

Clinical observation was made on 112 cases of middle ear infection treated by radical mastoidectomy.

The air and bone conduction audiometry were done before and after the operation. Objects were divided into five different groups from the degree of the pre-operative air conduction hearing.

In each group, the changes of the post-operative bone and air conduction were studied, and the relationship between the changes of hearing and the state of the tympanic membrane, the impairment of auditory ossicles, the existence of cholesteatoma, and the duration of otorrhoea, were observed.

From the results, the author stated that the pre-operative hearing of chronic suppurative otitsl media treated by radical mastoidectomy was mainly influenced by the state of the perforation of the tympanic membrane, the bone conduction hearing, and the sound transmitting ability of pathologicai conductive apparatus including the ossicles and healty tissues of thefmiddle ear.

\section{中耳根治手術と術前聴力に関する研究}

\section{東京大学医学部耳悬咽喉科学教室（主任 切替一郎教授）}

松岡哲 郎

\begin{tabular}{|c|c|}
\hline \multicolumn{2}{|r|}{ 目 } \\
\hline 第1音 & 維 \\
\hline 第2章 & 研究方法 \\
\hline 第3 章 & 研究成續及び拸按 \\
\hline 第 4 章 & 総括及び結論 \\
\hline & 交＼cjkstart塥 \\
\hline
\end{tabular}

慢性中耳炎に対して中耳根治手術を行う時，先ず臨床 的見地から術前聴力が問題となる。近年，各璉の聴力增 進根治手術が提唱されその成績が在来の根治手術と比較 検討されて福りながら中耳根治手術の術前術後の聴力の 変化についてあまり詳細な検討が行われていないように 思われる・著者は既に中耳根治手術と聴力の関係につい て推計学的検討を加え伝音機構の変化と聴力の変動につ

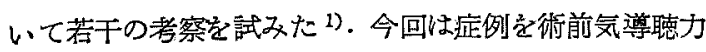
損失の程度より 5 群に分類し，その各群の術後の聴力変 化及びその各群と中耳病変との関係を検討しある一定の
傾向を認めたように思われるのでこっに報告する・なお 分類方法は推計学的根拠より標本平均, 標準偏差を用い て対象を 5 階級に分類し，他の聴力堌進根治手術の成綪 とる容易に比較し得るようにした。

本論文の研究史上の意義については既に発表した中耳 根治手術と聴力関する研究 一々の推計学的考察

一、慢性中耳炎のオージオグラム2)の続編とみたり・

\section{第 2 章 研究方法}

研究対象は松岡 1) (1958) と全く同一で112 例の根治 手術症例である。(手術方法は原則として Zaufal 氏流) な特測定装置及び方法，測定值の推計的処理方法も全く 松岡り（1958）と同しで，気導及び骨導聴力型の分類は 松岡 2)（1958）によつた。今回は資料を整理するために 中耳根治手術病糜を作成し，手術前後㳄次のような検索 を行い成績を記入した。

1. 手術前：氏名, 性別, 年令、診断名, 発症年月 日, 耳漏持続期間, 主訴, 中耳疾患既往歴を記入乙, . 
ージオメーターによる気尊, 骨導検查成縝, 咡語及び会 話語検查成績, 前庭㙨能温度刺战㭘查 (Bárány 氏法) の成績を記載した。

2. 手術時：手術年月日, 鼓膜所見（殊に穿孔部位及 びその大さ形態）真珠腫の有無，乳様洞，鼓室等の各部 の大さ, 膿汁の有無, 肉芽の状態に注意し硬脳膜, $S$ 字 状洞その他の所見にも留意して手術所見を記載した。

な鼓室小骨は，桘，砧骨及ざ鐙骨の消失や肉芽附着 状態及び関節部分の変化に注意し，摘出せる鼓室小骨は ルーぺにて拡大しスケッチを行い欠損部及びカリェスの 有無，肉芽の附着状態“観察したが，この詳細についし は佐藤（靖雄）博士 ${ }^{3)}$ 4)（1955）の教示によつた。

3. 手術後：手術創腔の完全上皮化後に 患者之再び来 院させ，次のような点について検索学行いその成績を記 入した.

手術創腔の完全上皮化に要した日数，手術創腔の上皮 化つ状態（殊に正円空及心゙卵円空附近及び耳管開口部の 所見), オージオメーダーに上る気尊及び骨導検查成績, 咡語及び会話語検查成績, 前庭㙨能温度刺㦸挨查 $\left(27^{\circ} \mathrm{C}\right.$, $20 \mathrm{cc}$ ) 及び廻転刺㦸検查（Bárány 氏法）の成績を記載 した.

以上の研究方法による成績を主に術前聴力と中耳病変 との関係を中心に色々の角度から整理して次の如き研究 成績安得た。

なお本交及び表中の聴力損失 $\mathrm{db}$ 值は気導. 骨導とも 言語周波数帯域平均值て，2000cps をadb, 1000eps を bdb, 500cps を $\mathrm{cdb}$ とすると, $(\mathrm{a}+2 \mathrm{~b}+\mathrm{c}) / 4 \mathrm{db}$ であ $\eta$, 手術前後の聴力变動の $d b$ 值は, 気導, 骨導々も言 語周波数帯域平均値の（術前聴力一術後聴力）であり， $Z=\left\{(a+2 b+c) / 4-\left(a^{\prime}+2 b^{\prime}+c^{\prime}\right) / 4\right\} d b$ で求められ， 術後植力が増進した場合は (+), 術後聴力が㗚化した 埸合には (一)を $\mathrm{db}$ 值の前に附して表した。以下本 論文件の特に周波数のことわりの無、気導及び骨導聴力 $の \mathrm{db}$ 值及び手術前後の 聴力変動, 測定誤差の $\mathrm{db}$ 值 注前述の如く処理された值である。

\section{第 3 章 研究成綪及び考按}

すでに Asherson ") (1948) は，479例の各種中耳疾 患を観察し術前気導聴力と鼓膜所見に対して検討を加え ている・しかしながら詳紬な鼓室病変についての㭘討惊 認められない，著者は112 例の根治手術症例を言語周波 数帯域における術前気導聴力損失の程度により分類し, 分類された各群と鼓膜穿孔の形，鼓室小骨の久損状況， 平均䍜患年数, 性別, 年令, 真珠腫の有無, 手術後に気
尊聴力の落着く範囲，平均骨導聴力及び骨導聴力型等と の関係艺観察した。

また幾つかの群に分つに際し，著者が勝手に分類して しまうのを避けなるべく普遍的な方法によりたい、と考 えすすでに今迄饬られている推計学的周知事項を整理 し，普遍的な分類方法を考察した。

先ず今までにすで知られている推計学的事項 ${ }^{12 を ~}$ 整理してみると次の如くである.

1. 中耳根治手術耳術前気導聴力損失

i. 平均值， $52.3 \pm 1.517 \mathrm{db}$ (危険率 $5 \%$ )

ii. 言語周波数带域平均值（危换率 $5 \%$ ） $53.2 \pm 3.08 \mathrm{db}$ iii. 各周波数の平均值（危険率 $5 \%$ )

$\begin{array}{rl}125 \mathrm{cps} & 45.5 \pm \alpha \mathrm{db} \\ 250 " \text { " } & 53.0 \pm 2.9 \mathrm{db} \\ 500 \text { " " } & 53.3 \pm 3.5 \mathrm{db} \\ 1007 \text { " " } & 51.7 \pm 2.9 \mathrm{db} \\ 2000 \text { " " } & 51.3 \pm 2.9 \mathrm{db} \\ 4000 \text { " " } & 49.6 \pm \alpha \mathrm{db} \\ 8000 \text { " " } & 43.0 \pm \alpha \mathrm{db}\end{array}$

2. 中耳根治手術耳術前骨導聴力揁失

i. 平均値 $5.95 \pm 1.53 \mathrm{db}$ (俈険率 $5 \%$ )

ii. 言語周波数带域平均值（危険率 $5 \%$ ) $5.00 \pm 3.90 \mathrm{db}$ iii. 各周波数の平均值 (危険率 $5 \%$ )

$\begin{array}{cc}250 \mathrm{cps} & 2.4 \pm 3.0 \mathrm{db} \\ 500 ", & 1.2 \pm 3.3 \mathrm{db} \\ 1000 " \text { " } & 5.1 \pm 4.0 \mathrm{db} \\ 2000 " \text { " } & 6.8 \pm 4.3 \mathrm{db} \\ 4000 \text { " " } & 10.9 \pm 5.0 \mathrm{db} \\ 8000 \text { " " } & 15,2 \pm \mathrm{adb}\end{array}$

3. 相関々係 (言語周波数帯域)

i. 中耳根治手術 耳術前 骨導聴力損失上術後骨導聴力 損失とは正の相関々係にある. $(r=+0.394$ 危険率 $5 \%)$

ii. 中耳根治手術耳術前気導聴力損失々 術前骨導聴力 損失とは正の相関々係沈ある. $(r=+0.483$ 危険率 $5 \%)$ 4. 中耳根治手術耳術前気導聴力型 ${ }^{2)}$

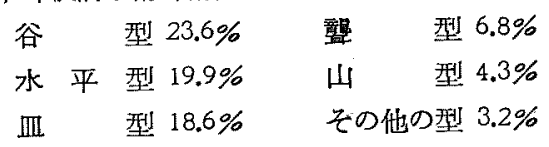

高音漸傾型 $14.3 \%$

低音障碍型 $9.3 \%$

5. 中目根治手術耳術前骨導聴力型 2)

基線水平型 $18.0 \%$ 水 平 型 $12.0 \%$

高音急塗型 $16.0 \%$ 高 音 漸 $12.0 \%$ 
断 層 型 $14.0 \%$ 高音漸傾型 $14.0 \%$ (高度)

分類方法の考察

根洽手術症例を術前気覚聴力損失の程度より幾つかの

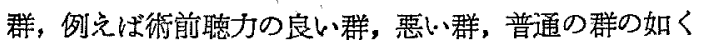
分類して各群の実数，骨導聴力，術後の気尊聴力, 鼓膜 穿孔の状態,鼓空病变等との関俰高検討寸るため,推計学 的な立場から普遍的な分類方法について考察してみた。

第 1 表 標本の分類（5群に分けたのを示す）

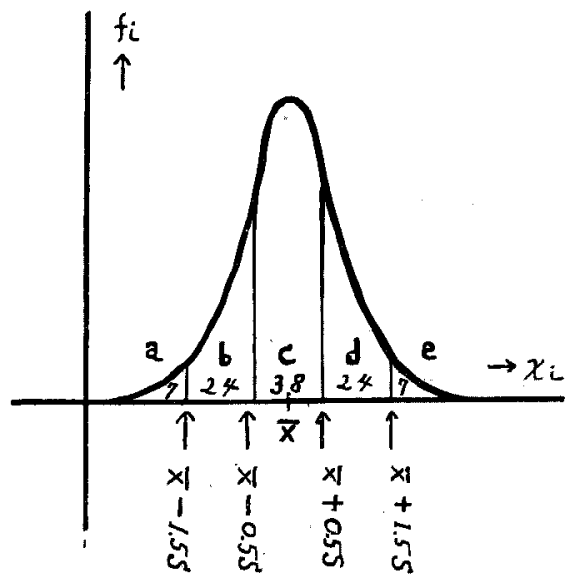

第 2 表 分頪された喿群

\begin{tabular}{|c|c|c|c|}
\hline & 階 级 & 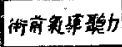 & \\
\hline а 群 & $\bar{x}-155 \sim 415$ & $3 O_{d b}$ we & 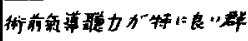 \\
\hline b群 & $\bar{x}-0.5 s+\bar{x}-15,5$ & $30 \sim 4586$ & 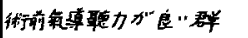 \\
\hline C群 & $\bar{x} \pm 055$ & $x 5 \sim 60 \mathrm{db}$ & 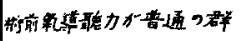 \\
\hline 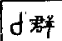 & $\bar{x}+0.05-\bar{x}+15 s$ & $60 \sim 75 \mathrm{db}$ & 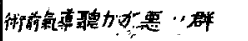 \\
\hline e群 & $\bar{x}+1.5, S \sim 4<\div$ & $75 \mathrm{db}$ uS & 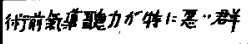 \\
\hline
\end{tabular}

分類すると第 2 表に示す如くになり各群を袁の如く $a$ ， b, c, d, e 群の 5 群に分つた場合, その臨床的意義は表 示の如く考点て差支克ないよに思われる.

また標本が正規分布と見なして良い場合には，区間 $\overline{\mathbf{x}} \pm \mathrm{s}$ に度数の約 $68 \%$ (ほ $2 / 3$ )，区間 $\overline{\mathbf{x}} \pm 2 \mathrm{~s}$ K約 95

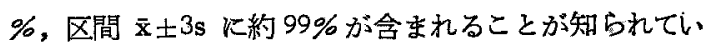
る. 中耳根治手術耳術前気等聴力では $\overline{\mathrm{x}}=53.2, \mathrm{~s}=15.8$ の值がすで知られておりこれより計算すると：任ら $95 \%(\overrightarrow{\mathrm{x}} \pm 2 \mathrm{~s})$ は $20 \sim 85 \mathrm{db}$ の範囲に，ほ 2/3）は 35〜70db の範囲にあると 臨床的には考えられ Ђ.

著者は 112 例の標本を第 2 表の如く 5 群に分類し，そ の各群と鼓室病変及ざ臨床的諸因子その関倸を掵討し別 表に示す如き成續を得た，以下順を追つて各項目につい て若干の検討及び考察を加えてみる。
標本が正規分布する場合，平均

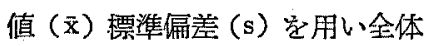
を5つの階級に分けると各階級の 度数の\%は次の如くなることが知 られてにる（第 1 表参照）。

$$
\begin{array}{lr}
\overline{\mathrm{x}}-1.5 \mathrm{~s} \text { 以下 } & 7 \% \\
\overline{\mathrm{x}}-1.5 \mathrm{~s} \sim \overline{\mathrm{x}}-0.5 \mathrm{~s} & 24 \% \\
\overline{\mathrm{x}}-0.5 \mathrm{~s} \sim \overline{\mathrm{x}}+0.5 \mathrm{~s} & 38 \% \\
\overline{\mathrm{x}}+0.5 \mathrm{~s} \sim \overline{\mathrm{x}}+1.5 \mathrm{~s} & 24 \% \\
\overline{\mathrm{x}}+1.5 \mathrm{~s} \text { 以上 } & 7 \%
\end{array}
$$

この際 $\overline{\mathrm{x}} \pm\{(\mathrm{N}+1) \mathrm{F} / \mathrm{N}\}^{1 / 2}$ の範囲外の症例以例外として取报 うの方適当である。

そこで実際に対象となる中耳根

\begin{tabular}{|c|c|c|c|c|c|c|c|c|c|c|c|c|c|c|}
\hline \multirow[b]{2}{*}{ f } & \multirow{2}{*}{$\begin{array}{l}\text { 㝝 } \\
\text { 慗 } \\
\text { \% } \\
\%\end{array}$} & \multirow{2}{*}{ 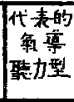 } & \multicolumn{2}{|c|}{ 骨 等 } & \multirow{2}{*}{ 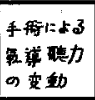 } & \multirow{2}{*}{ 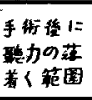 } & \multirow{2}{*}{ 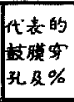 } & \multirow{2}{*}{ 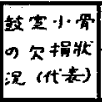 } & \multirow{2}{*}{$\begin{array}{l}\text { 平均 } \\
\text { 羅患 } \\
\text { 年数 }\end{array}$} & \multirow{2}{*}{ 平均 } & \multicolumn{2}{|c|}{ 性别 } & \multicolumn{2}{|c|}{ 桌珠䏦 } \\
\hline & & & 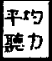 & $\begin{array}{l}\text { 代表的 } \\
\text { 琶加力型 }\end{array}$ & & & & & & & 男 & 女 & 有 & 繁 \\
\hline 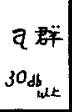 & $\begin{array}{l}6.7 \\
173\end{array}$ & 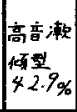 & 0.75 & $\begin{array}{c}A \text { 群 } \\
75 \% \\
\%\end{array}$ & $\begin{array}{c}5 \sim 25 \mathrm{db} \\
\text { 悪化 }\end{array}$ & $25-50$ & $\begin{array}{l}\text { 上却室 } \\
\text { 穿弗 } \\
85.7 \%\end{array}$ & 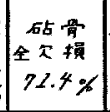 & $\begin{array}{r}12.3 \\
\text { 年 }\end{array}$ & $\begin{array}{r}18.3 \\
7\end{array}$ & 3 & 4 & $\left|\begin{array}{c}1 \% 0 \\
\%\end{array}\right|$ & \\
\hline $\begin{array}{r}b \text { 群 } \\
302 \text { 好 } \\
\text { ds }\end{array}$ & 23.2 & 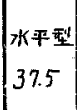 & 1.25 & $\begin{array}{l}A \text { 群 } \\
500\end{array}$ & $\begin{array}{l}0 \sim 20 \\
\text { 悪 }\end{array}$ & $25 \sim 65$ & 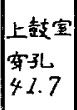 & 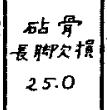 & 12.1 & 21.2 & 15 & 9 & 583 & $\begin{array}{r}16.7 \\
\%\end{array}$ \\
\hline $\begin{array}{r}C \text { 辟 } \\
45 \sim 60 \\
d b\end{array}$ & $\begin{array}{l}36.5 \\
638 .\end{array}$ & $\begin{array}{l}\text { 요 } \\
34.2\end{array}$ & 9.50 & $\begin{array}{l}A \text { 群 } \\
46.2\end{array}$ & 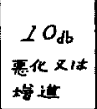 & $35-65$ & $\begin{array}{l}\text { 中心 } \\
\text { 象孔 } \\
44.6\end{array}$ & $\begin{array}{l}\text { 㕷骨 } \\
\text { 全久損 } \\
28.9\end{array}$ & 11.9 & 22.6 & 26 & 12 & 63.2 & 237 \\
\hline 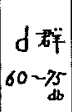 & $\begin{array}{l}26.0 \\
(27)\end{array}$ & $\begin{array}{l}\text { 谷型 } \\
370\end{array}$ & 7.00 & $\mid \begin{array}{l}\text { B 群 } \\
50.0\end{array}$ & $\begin{array}{l}0-20 \\
\text { 增透 }\end{array}$ & $40-75$ & $\begin{array}{l}\text { 中心 } \\
\text { 穿开 } \\
55.5\end{array}$ & 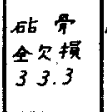 & 14.8 & 22.3 & 11 & 16 & 704 & 222 \\
\hline $\begin{array}{l}\mathrm{e} \text { 群 }^{2} \\
75_{\mathrm{d}}^{\mathrm{W}}\end{array}$ & 27 & $\begin{array}{l}\text { 谷程 } \\
37.5\end{array}$ & 27.0 & $\mid \begin{array}{l}C \text { 群 } \\
98.0\end{array}$ & $\begin{array}{l}5-25 \\
\text { st } \\
\text { s遭. }\end{array}$ & $50-75$ & $\mid \begin{array}{l}\text { 中心 } \\
\text { 实尒 } \\
37.5\end{array}$ & 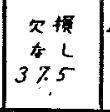 & 13.0 & 22.4 & 6 & 2 & 75.0 & 250 \\
\hline $\begin{array}{l}\text { 例外 } \\
\text { (全萍) }\end{array}$ & $\begin{array}{l}2.7 \\
(8)\end{array}$ & $\mid \begin{array}{l}\text { 禁型 } \\
2000.0\end{array}$ & 480 & $\mid \begin{array}{l}C A \\
1000\end{array}$ & 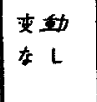 & 全萃 & 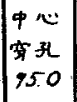 & 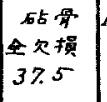 & 15.6 & 22.6 & 8 & 0 & 375 & 625 \\
\hline
\end{tabular}
治手術耳の術前気䤃聴力損失の度 数分布表より $\overline{\mathrm{x}}$ ， $\mathrm{s}$ を求めると $\overline{\mathrm{x}}=53.2, \mathrm{~s}=15.8$ となり萃却限界 は $56.5 \pm 38.1$ (㧥険率 $5 \%$ ) とな り，対象となる標本学前述の如く

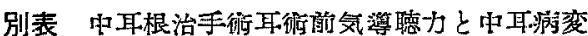


1. 各群の実数及び\%：第 2 表に示した如く 、 群は術 施気導聴力が $30 \mathrm{db}$ 以上の群で臨床的には術前気導德力 が特に良い群と考光られ $6.7 \%$ (7 例) 認めらた， b 君 は術前気尊聴力が $30 \sim 45 \mathrm{db}$ の群で臨床的には術前気 導聴力が良い群と考兄られ $23.1 \%$ (24 例) 認められる。 c 群は術前気導聴力が $45 \sim 60 \mathrm{db}$ の群で臨床的には術前 気尊聴力が普通の群と考えられる $36.5 \%$ (38例)認めら れ d 群は術前気導聴力が $60 \sim 75 \mathrm{db}$ の群で臨床的には 術前気導聴力が悪い群と考えられ 26.0\% (27 例) 認めら れる・e 群は術前気導聴力が $75 \mathrm{db}$ 以下の群で臨床的に は術前気尊聴力が特に悪い、群と考光られ $7.7 \%$ (8例) 認 められる.な括この他例外として術前に后よ゙全警の症例 が $7.1 \%$ (8例) 認めら衣た。

2. 各群の手術前後の気尊聴力の变動, 亚びに術後気導 聴力

各群の気導聴力が手術に上りどの程度变動するかり そ

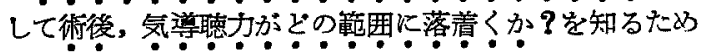
に各群の手術前後の気導聴力の変動の $\overline{\mathrm{x}}, \mathrm{s}$ 及び各群の 術後気尊力の $\bar{x}, \mathrm{~s}$ 度数分布非上り求め区間 $\overline{\mathrm{x}} \pm 2 \mathrm{~s}$ に 全体の約 $95 \%$ の度数が含まれることより 計算して各群の気尊妿手術によりどの程度変動するか術 後どの範囲に落着くかを推定した。この成綪を第 3 表に 示す.

\begin{tabular}{|c|c|c|c|}
\hline & \multirow{2}{*}{\multicolumn{2}{|c|}{ 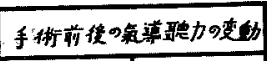 }} & \\
\hline & & & \\
\hline & 平均值 & 大略の变和 & $\bar{x} \pm 25$ \\
\hline a萑 & $(-1)<9 d 6$ & $(\rightarrow 5-(\rightarrow 25)$ & $37.2 \pm 2 \times 70=25 \sim 50_{d b}$ \\
\hline b群 & $(\rightarrow) 7.1$ & $0 \sim(-) 20$ & $471 \pm 2 \times 103=25 \sim 65$ \\
\hline C群 & (t) 5.4 & $(-1) / 0 \sim(+) 10$ & $500 \pm 2 \times 73=35 \sim 65$ \\
\hline d群 & $(+) \quad 26$ & $0-(t) 20$ & $577 \pm 2 \times 97=40 \sim 75$ \\
\hline e群 & $(t) 11.3$ & (t) $5 \sim(t) 25$ & $61.7 \pm 2 \times 69=50 \sim 75$ \\
\hline
\end{tabular}

すなから a 群(術前 $30 \mathrm{db}$ 以上の群) は手術により $5 \sim 25 \mathrm{db}$ 悪化して術後 25 50db の籍团に聴力が落着 ‘ b 群 (術前 $30 \sim 45 \mathrm{db}$ の群) は手術により $0 \sim 20 \mathrm{db}$ 悪化 しで術後 25〜65db の範国飞，また $\mathrm{c}$ 群（術前 45 60db の群）は手術により $10 \mathrm{db}$ 悪化又は堌進して 術後 35 65db の範团に聴力か落着く. d. 群 (術前 60 $\sim 75 \mathrm{db}$ の群）は手術汇より 0〜20db 増進して術後 40 〜 75db の範囲火，また e 群（術前 $75 \mathrm{db}$ 以下の群）は 手術により 5〜25db 増進して術後 50〜75db の籍囲に 聴力が落着く . 以上の手術による気導聴力の变動は既に 報告した推計学的結論 ${ }^{1)}$ と一致するよ 5 に思われる。
第 4 表 各涪の気溥聴力型実数

\begin{tabular}{|c|c|c|c|c|c|c|}
\hline & マ群 & b群 & C群 & d群 & e群 & 例办 \\
\hline 高昔濑顷型 & 3 & 3 & 5 & 5 & 1 & 0 \\
\hline 水平型 & 2 & 9 & 7 & 4 & 2 & 0 \\
\hline 血 型 & 0 & 3 & 13 & 7 & 2 & 0 \\
\hline 谷 型 & 1 & 3 & 5 & $10^{\circ}$ & 3 & 0 \\
\hline 但音阵碍型 & 0 & 4 & 5 & 0 & 0 & 0 \\
\hline 型 & $I$ & 2 & 0 & 1 & 0 & 0 \\
\hline 势 型 & 0 & 0 & 0 & 0 & 0 & 8 \\
\hline 其の他の型 & 0 & 0 & 3 & 0 & 0 & 0 \\
\hline
\end{tabular}

3. 各群の気尊聴力型：各群の気導聴力型を 検討した のを第 4 表に示したなな挌聴力型の 分類その他は松 岡2（1958）の報告を参照されたい，各群におい、て最も 多く認められる代表的気尊聴力型及びその\%は別表に示 したが a 群では高音泍傾型 (42.9\%) b 群では水平型 (37.5\%) c 群では且型 (34.2\%) d 群では谷型 (37.0\%) e 群では谷型 $(37.5 \%)$ であつて，例外の群では全例型 型であつた。

4. 各群の骨導聴力及び 骨導聴力型：各群の術前骨導 聴力の平均値及び代表的骨尊聴力型を検討した成續を別 表に示した，骨導聴力型の分類は松岡 2)（1958）によつ

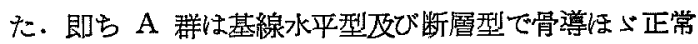
な場合の聴力型群であり $\mathrm{B}$ 群以高音急鉒型，高音渐傾 型 (軽度)，Carhart 型で骨導が軽度に障碍された場合 の聴力型群で $\mathrm{C}$ 群は水平型, 谷型, 高音漸傾型（高 度)，裂型等で骨導が明らが障碍された場合の聴力型 群である。

a 群（術前 $30 \mathrm{db}$ 以上の群）の骨導平均值は $0.75 \mathrm{db}$ ， 骨導聴力型は A 群に属する型が最る多く $75.0 \%$ 認めら れた. b 群 (術前 30〜45db の群) の骨導平均值は 1.25 $\mathrm{db}$ 骨導聴力型は A 群に属する型が最も多く50.0\% 認 められた．c 群（術前 $45 \sim 60 \mathrm{db}$ の群）の骨導平均值 は 9.50db 骨導聴力型は A 君に 属する型が最も多く 46.2\%認められた。しかし d 群（術前 60〜75db の群） では骨導平均値は $7.00 \mathrm{db}$ 骨導聴力型は B 群に属する 型が最も多く50.0\%認められ更に e 群(術前 $75 \mathrm{db}$ 以 下の群）では骨導平均值は，27.0db 骨導聴力型は C 群 に属する型が最も多く980\%認められる．以上より明 らかな如く

i. 術前気導聴力が 価くなるにつれて術前骨導聴力る 覀くなるが，このことは中耳根治手術耳術前気尊聴力損 
失と術前骨導聴力損失とが正の相閣々係 $(\mathrm{r}=+0.483$ 笽 険率 $5 \%$ ）にある1ことを臨床的に襄づけている。

ii：また中耳根治手術耳は術前気導聴力が約 $60 \mathrm{db}$ 位 までの群は大体骨導聴力も良く聴力型す $\mathrm{A}$ 群が最す多 くしめているが，60〜75db の群では B 群が最る多く $75 \mathrm{db}$ 以下の群になると骨導も明らかに障碍されて聪力 型も C 群が最も多く認められるようになる。

5. 各群に和ける鼓膜穿孔及び賣珠腫

楠岡一野田 ${ }^{6}$ (1951) は 572 例の慢性中耳炎を觀察し， 年令は 21〜30才に最も多く鼓膜穿孔部位は前下部が最 子多いとし，磯野7（1951）は慢性中耳炎は11〜20才 に最も多く，男性に多いとし慢性上鼓室炎の頻度は 34.5 \%であるとしている.著者は第5表に各群比ける鼓膜 穿孔部位を検語して示した。

第 5 表 各群における鼓膜穿孔部位及ど真珠迋

\begin{tabular}{|c|c|c|c|c|c|c|c|c|}
\hline & \multirow{2}{*}{ 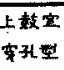 } & \multirow{2}{*}{ 耳 } & \multirow{2}{*}{ 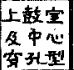 } & \multirow{2}{*}{\begin{tabular}{|l|} 
中心 \\
泺孔型
\end{tabular}} & \multirow{2}{*}{ 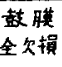 } & \multirow{2}{*}{ 不明 } & \multicolumn{2}{|c|}{ 廎珠胜 } \\
\hline & & & & & & & 有 & 無 \\
\hline a群 & $85.7 \%$ & $0 \%$ & $143 \%$ & $0 \%$ & $O_{\%}$ & $O_{\%}$ & 100 & $0 \%$ \\
\hline b群 & 41.7 & 20.8 & 42 & 33.3 & 0 & 0 & 58.3 & 16.7 \\
\hline C群 & 26.3 & 2.6 & 78 & 44.6 & 5.2 & 13.5 & 63.2 & 237 \\
\hline d群 & 25.9 & $O$ & 11.2 & 55.5 & 7.4 & 0 & 704 & 22.2 \\
\hline e群 & 250 & 12.5 & 12.5 & 375 & 0 & 125 & 75.0 & 250 \\
\hline
\end{tabular}

中耳仮性真珠腫の 形成機転 ${ }^{8)}$ に䦎しては慢性中耳炎 に続発して外耳道扁平上皮の鼓室内侵入増殖により 2 次 的炕発生するとい5 Habermann-Bezold の Einwanderungs-Theorie（外耳道表皮中耳腔堌殖説）が最も広 く行われているが, Wittmaack (1918), Lange (1924), Albrecht, Schwarze (1933) は別の見解を有している. (Habermann, 1889；Bezold；1890) 中耳仮性真珠腫

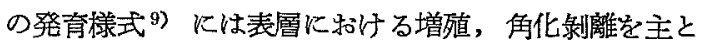

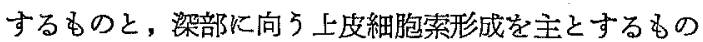
との2 型があり後者の場合ほ臨床的所芫に比し耳漏の脂 肪所見は単純なる慢性中耳炎のそれと大差なく誩断上の 注意を要するとされている。

著者の成績では

i a 群 (30db 以上の群) 更び b 群 $(30 \sim 45 \mathrm{db}$ の 群)では上鼓窒穿孔型が最も多く諗められ，術前気尊聴 力が亭い群には上鼓型型の中耳炎が多いと考党られた。

ii c 群 (45 60 db の群) d 群 $(60 \sim 75 \mathrm{db}$ の群) 及 び e 群 (75db 以下の群) Kは中心穿孔型务最も多く認 められ, 術前気尊聴力の悪、群には中心穿孔型の中耳炎 が多いと者えられた。 iii 耳革は b 群 $(30 \sim 45 \mathrm{db}$ の群) 火最も多く認めら れた。

iv 各群と真珠腫形成の有無との間には，明らかな関 保を認めなかつたが一般に各群共，真珠腫形成の㷵めら れる場合の方が明らかに多く例外として術前在心全啨の 群では真珠尰形成の認められない場合の方が明らかに多 からた・

6. 各群に和ける鼓室小骨の久損状況

慢性中耳炎の鼓室小骨の病変は，士でに堀内 10) (1935) が，鼓室小骨の変化の程度は病変に比例し殊に真珠腫で は著明で部分的欠損は檤骨に多く全欠損は砧骨に多いと して拉り，後藤（修）11）12（1956）は99例の慢性中耳 化膿淀の 手術定例にて $16 \%$ に鐙骨の運動性の障碍を諗 めている.

著者は鼓室小骨の欠損状況については，主な欠損が鼓 室小骨連鎖をどの部分で離断しているか即ら鼓空小骨連 鎖の離断の有無を中心に検討を加光，专の成績を第 6 表 に示した。

第 6 䒾 各群における鼓室小骨の久損状况

\begin{tabular}{|c|c|c|c|c|c|c|c|}
\hline & 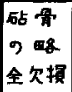 & $\begin{array}{l}\text { 砧骨 } \\
\text { 長 独 } \\
\text { の大损 }\end{array}$ & 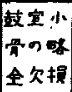 & 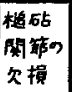 & $\begin{array}{l}\text { 其の他9 } \\
\text { 部吅 } \\
\text { 部欠損 }\end{array}$ & 不明 & $\begin{array}{l}\text { 欠揁 } \\
\text { L L }\end{array}$ \\
\hline 可群 & $71.4 \%$ & $O_{\%}$ & $14.3 \%$ & $14.3 \%$ & $O_{\%}$ & $O_{\%}$ & $O_{\%}$ \\
\hline b群 & 25.0 & 25.0 & 20.8 & 8.3 & 4.2 & 12.5 & 4.2 \\
\hline C群 & 28.9 & 18.4 & 18.4 & 10.5 & 2.7 & 5.3 & 15.8 \\
\hline d群 & 33.3 & 297 & 14.8 & 0 & 37 & 14.8 & 37 \\
\hline e群 & 25.0 & 25.0 & 12.5 & 0 & 0 & $O$ & 37.5 \\
\hline
\end{tabular}

i 各鼓室小骨欠損状況は第6表に示す如くで，こ れより中耳根洽手術耳術前気尊聴力と鼓室小骨連鎖の欠 損状況との閒には直接的に明らかな相互開係吕認められ ないように思われた。

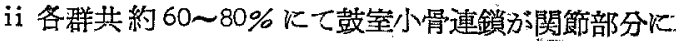
て離断されて和り，主要病変は各群共，砧骨のほざ全欠 損が約 25 35\% で最も多く次に砧骨の長脚欠損が約 20 〜30\%，鼓室小骨のほ心゙ 全欠損が約 10〜20\%，枮砧関; 節部の欠損による消失が約 10〜15\%諗められる。

iii 中耳根治手術耳術前気導聴力は鼓室小骨連䥊に括 ける離断の有無よりは伝音連鎖機能障碍の代償 (Kompensation) いかんにより大きく影響されると考えた.

鼓室小骨連鎖が骨欠損により離断されていたり関節部 分にかなり大きな骨欠損が諗められたにしても，この部

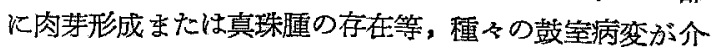


在することにより臌絮小骨連鎖が。障碍されていない時の インピーダンス整合に近い状態になつていることが臨床 的炕しばしば認められている。

鼓室小骨連鎖の重量は槌骨 $23 \mathrm{mg}$ ，砧骨 $25 \mathrm{mg}$, 鐙骨 2 3mg (Fletscher 18), Eithelberg ${ }^{18)}$ ) で, 全重量 $01 \mathrm{~g}$ 14) であるが中耳炎の際，鼓案小骨に附着する肉芽 は 50〜 100 mg 19) にもなり，質量の関係からも推定さ れる。

ま心動物実験におい、て蝸牛の Electrical activityを 音響伝導つ indicator として用うることができ，Wever and Bray は砧鐙関節に和ける関節離断及び砧骨の一 小部分の除去の前後に括ける中耳伝音能率をこの方法て 比較したが伝音連鎖離断によって起る可聴闇値の上昇は 平均約 60db であったし，また金武 15)（1954）も同様 に動物実験で中音域で平均約 $50 \mathrm{db}$ であるとしている. それにる拘らず別表及び第6表より明らかの如く術前気 導聴力分平均 $30 \mathrm{db}$ 以上の症例が $6.7 \%$ 它認められ，ま た 30〜45db の症例が $23.1 \%$ 認められ， しかも鼓室小 骨連鎖はいずれる大部分何等かの形で離断されている点 から考えてる，障碍された鼓至小骨連鎖に対し鼓堂病変 が巧にインピーダンス整合を行つているすのと思われ， この状態气 伝音連鎖機能障碍の代償（Kompensation） そ仮称した。

7. その他の因子との関保： Maxwell \& Richter ${ }^{16)}$ (1940) は 2-A オージオメーダーにて計測し， 256, 512, $1024,2048 \mathrm{cps}$ を平均乙会話音域の平均㯖力損失々し耳 漏持続期間と術前気尊聴力との関係を検討しているが認 むべき関係がなからたとしている。

著者恃各洋の平均䍜患年数，性別，年令等々術前気尊 恥力との関係を検討したが明らかな知見を得られなかつ た。

8. 各磁に拾ける手術時の鼓室病変

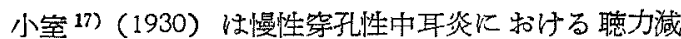
退の一原因は卵，正円空上の厚い、粘膜乃至肉茅層あるい は表皮形成，あるい、は洀疸形成のための音波の伝導不全 とあるとしている。しかし中耳根治手術泪祭し手術前後 の聴力の関係老中心に系統的に手術時つ鼓室病変を検討 した報告は少いように思われたので著者はこの点につい て第 2 章にのべた如き方法で検禁怘行い次の如き成績を 得た.

1. a 群（術前気導聴力が $30 \mathrm{db}$ 以上の群） 上鼓室 型で真珠腫（有）100\%

i この群は全部，鼓膜所見に上鼓案穿孔が認められ手
術に際し真珠腫が上鼓室にのみ限局して介在するのが諮 められ，また鼓室小骨連鎖は何等かの形で離断されてい、 るがその部索状の真珠迁や弛緩せる肉芽等があたかる 欠損した豉室小骨連鍞部を連絡するように介在して、る のが多く認められる。

ii 術前気遒聴力の 良いのは, 鼓膜のほ心健存, 上鼓 堂にのみ限局せる病変，伝音連鑜機能障碍の代償等によ るものと思われる。

$2 . \mathrm{b}$ 群（術前気導聴力が $30 \sim 45 \mathrm{db}$ の群）この群 の代表的な鼓室病変は次の 3 つの型で焉る.

i 上鼓室穿孔型で真珠腫（有）(41.7\%) 伝音連鎖は鼓 室小骨の欠損により多くは離断されているが鼓室内に真 珠腫，肉芽が充満していたりまた亄膜祭張部が鼓堂岬と 瘉着している所見等が認められ伝音連鎖機能障碍の代償 が考えられる。

ii 耳草形成 (20.8\%) 鼓室小骨は注よ゙全欠損に近く鼓 意内に真珠腫を混じた肥厚せる粘膜及び肉芽組織が充満 して窓の方にまで及んでいる。

iii 中心穿孔型で真珠腫 (無) $(16.5 \%)$ 鼓膜緊張部に 大きな中心穿孔があり鼓室小骨連鎖には肉芽附着，カリ ェス形成等の所見はあるが鼓室小骨連鎖には離断が認め Бれない.

$3, c$ 群 (術前気尊聴力が $45 \sim 60 \mathrm{db}$ の群) この群 の代表的鼓室病变次次の 4 つの型でする。

i 中心穿孔型（または鼓膜のほざ 全欠損）で真珠䭪 （有）(26.3\%）鼓室小骨連鑜は椎骨及び 砧骨が大部分欠 損している.

ii 上鼓案穿孔型で 真珠腫（有）(21.1\%) 鼓空小骨連 鎖は多くは砧骨消失又は砧骨長脚欠損の形で離断してい る・また卵円空附近に真珠腫の存在する泟例が認められ $る$.

iii 中心穿孔型で真珠腫（無）(18.4\%)この型は真珠 腫形成は認められないが鼓室小骨連鎖は多くの場合，砧 骨のほよ゙全欠損又は砧骨長脚欠損の形で離断している。

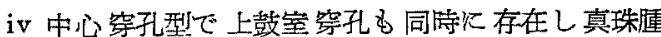
(有) $(7.9 \%)$ 鼓室小骨連鎖は全例に砧骨の全欠損が認め られる。

4, $\mathrm{d}$ 群 (術前気遒聴力が $60 \sim 75 \mathrm{db}$ の群) この群 の代表的鼓室病变は炊の 4 つの型である.

i 中心穿孔型（攵は䚳膜の注ざ全欠損）で真珠腫(有) (37.0\%) 鼓室小骨連鎖は大部分砧骨長脚の欠損又心砧 骨，赖骨のほざ全欠損の形で離断されて括り真珠腫は側 頭骨の各䗋简に広? 侵入し，水平半覞管骨壁に瘦孔を作 
つている症例も認められる。

ii 上鼓室穿孔型で真珠腰（有）(25.9\%) 鼓室小骨連 鎖は全例にて砧骨のほぶ全欠損の形で離断されて特り， 一般に他の群に比して真珠腪の侵殰が強く硬脳膜の露 出, 硬䋞膜外膿瘍, $S$ 字状洞周囲膿瘍, 水平半規管骨壁 に瘦孔形成等の所見が認められるものがある。

iii 中心穿孔型で真珠腫 (無) $(14.8 \%)$ 鼓室病変は主 に卵円空附近飞強く鼓室小骨運鑜は全部砧骨長脚で離断 されている。

iv 中心穿孔で上鼓室穿孔す同時に存在し真珠腫（有） (7.4\%) 鼓室小骨連鎖は砧骨長脚で 離断されて垎り卵円 空简，迷路周囲蜂窝に真珠連が強く侵献している.

$5, \mathrm{e}$ 群 (術前気導聴力が $75 \mathrm{db}$ 以下の群) この群 の代表的な鼓宔病变は次の 3 つ型である.

i 中心穿孔型で 真珠腫（有） $(25.0 \%$ ) 鼓室小骨連鎖 は大体離断されており水平半規管に瘦孔の認められるる のが少くない。

ii 上鼓室穿孔型で真珠腫（有）(25.0\%) 鼓室小骨連 鎖は砧骨長脚部で欠損し卵円空窝に真珠腫の認められる 症例及び明らかな迷路梅毒の 1 例が認められた。

iii 中心穿孔型で真珠腫（無）(12.5\%) 鼓䆓小骨連鎖 はほ亡゙健存するも限局性迷路炎の症状が認められた。

6. 例外の群（術前気導聴力がほ心゙全算の群）

i 中心穿孔型（または鼓膜のほ心゙ 全欠損）で真珠腫 (無) $(62.5 \%)$ 卵円空附近に限局した浮腫性の粘膜肥厚 を主な病変とした症例が、かなり認められる。

ii 中心穿孔型（または鼓膜のほざ全欠損）で真珠庫 (有) $(37.5 \%)$ 急激に昡最登発来した症例, 顔面神経麻 瘦を発来した症例が認められる。

iii 例外の群に特有なのは 20 寺前後の男子が多! 鼓膜 所見は中心穿孔型（または鼓膜のほゔ全欠損）で真珠腫 は尧しろ認められないことが多い，そして必ずしす真珠 腫による卵门空附近の病変を伴わずた鼓室小骨連鎖の 病変も一定でない。

恐らくは切替一北山 20)（1953）が考察した如き機転 で神経難聴を発来し易い素因の者が慢性中耳炎の経過中 に何等かの誘因で算になってくるものと惟定され大多数 の症例方術前に眩最その他の内耳症状を経験している。

\section{第 4 章 総括及び結論}

東京大学耳悬咽揬科に和いて慢性中耳炎に中耳根治手 術を行つた 112 例について，術前聴力と中耳病変の関係 に検討を加え次の如く結論した。

1. 根治手術症例を術前聴力損失の 程度より 幾つかの
群，例学ば術前聴力の良い、群，覀い群，普通の群の如く 分類してその各群と種々の中耳病変との関保觉検討する に際して普遍的な分類方法によりたいーと考充推計学的根 拠より術前気遒聴力損失の度数分布より標本平均，標準 偏差を用いて対象を 5 階級に分類する方法を考察しこれ を提唱した。

2.この分類方法より 112 例の対象を 5 群に分類した。

$a$ 群：術前気導聴力が $30 \mathrm{db}$ 以上の群 (術前気導㯖力が特に良い群)

b 群：術前気尊聴力が $30 \sim 45 \mathrm{db}$ の群 （術前気導聴力が良い群）

$c$ 群：術前気尊聴力が $45 \sim 60 \mathrm{db}$ の群 （術前気導聴力か゚普通の群）

$\mathrm{d}$ 群：術前気導聴力が $60 \sim 75 \mathrm{db}$ の群 （術前気尊聴力が悪以群）

e 群：術前気導聴力が $75 \mathrm{db}$ 以下の群 （術前気導聴力が特に悪い、群）

3. 112 例の詨象を上記の如く分類すると a 群は $6.7 \%$ (7 例), b 群忙 $23.1 \%$ (24 例)，c 群忙 $36.5 \%$ (38 例)， $\mathrm{d}$ 群は $26.0 \%$ (27 例), e 群は $7.7 \%$ (8 例)認められ,

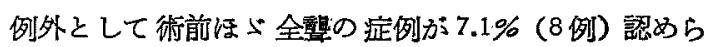
炾た。

4. a 群は手術により 5〜25db 悪化して術後 25〜50 $\mathrm{db}$ の範囲に聴力が落着き， $\mathrm{b}$ 群は $0 \sim 20 \mathrm{db}$ 悪化して 術後 $25 \sim 65 \mathrm{db}$ の範囲に，また $\mathrm{c}$ 群は $10 \mathrm{db}$ 覀化また 江増進して術後 35 65db の範围に聴力が落着き， $\mathrm{d}$ 群 は 0〜20db 堌進して術後 $40 \sim 75 \mathrm{db}$ の範囲に, また e 群は 5〜25db 増進して術後 50〜75db の範囲に聴力が 落着くものと推定される。

5. 術前気端聴力が䄪 $60 \mathrm{db}$ 采での群 $(\mathrm{a}$ 群, $\mathrm{b}$ 群, $\mathrm{c}$ 群)では骨尊聴力す良く保たれており，d 群では骨導に 軽度の障碍が，e 群では骨尊に明らかな障碍が認められ ることが多い。

6. 術前気導聴力の良い群（a 群， b 群）には上鼓室 穿孔型の中耳炎が多く, 術前気導聴力の悪い群 ( $\mathrm{d}$ 群, e 群) には中心穿孔型の中耳炎が多い。

7. 慢性中耳炎の鼓室小骨連鎖は骨欠損により離断さ れていることが多く，砧骨の汪ら゙全欠損をたは砧骨長脚 欠損の形で障碍されていることが多い。

8. 術前気尊恥力の良い群（ $\mathrm{a}$ 群， $\mathrm{b}$ 群）では鼓室小 骨連鑜が骨欠損により何等かの形で離断されていてる， この部に弛緩した肉莱や索状の真珠腫等が介在して障碍 された鼓室小骨連鎖に対し鼓室病変が污にインピーダン 
ス整合を代行していると思われる所見が少くないが，こ のような状態を伝音連鎖機能障碍の代償と仮称した。

9. 中耳根治手術 耳術前気導媤力は 鼓室小骨連鎖の 離 断の有無よりは伝音連鎖機能障碍の代償の有無により大 きく影響されると考えた。

10, 術前気導聴力の良い群 ( $\mathrm{a}$ 群, $\mathrm{b}$ 群) では鼓膜の 上鼓窒に穿孔があり鼓膜は大部分が残存し, 上鼓室にの み限局せる真珠腄病変, 伝音連鎖㙨能障碍の代償等が代 表的な病変であり，術前気暗聴力の悪い群 ( $\mathrm{d}$ 群, e 群) では中心穿孔による豉膜の大きな穿孔, 卵円空や正円空 附近，迷路周囲蜂简その他広く側頭骨に㹡がつた真珠腫 病変, 鼓堂小骨連鎖の離断等が代表的な中耳病变であ 方。

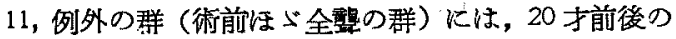
男子が多く，中心穿孔型（また臌膜のほよ゙全欠損）で 真珠腫形成は認められないことが多い。

12, 各群と鼓膜穿孔の形, 鼓室小骨の欠損状況，平均 痽患年数, 性別, 年合, 真珠尰の有無, “気遒聴力型, 手 術による気尊聴力の変動, 手術後に気導聴力の落着く範 囲, 平均骨導聴力型等との関俰は別表に示した如くであ る。

13. 中耳根治手術耳術前気導聴力は主に，術前骨導聴 力の良否，伝音連鎖機能障碍の代償の有無，また鼓膜穿 孔の部位及び形態により大きく規定さ礼る。

(な怙聴力損失の $\mathrm{db}$ 值はすべて 言語周波数带域つ平 均值である).

\section{文献}

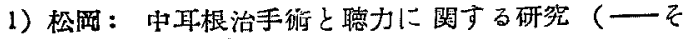
の推計学的考察 一), 日耳學, 61,7, 1958. 2) 松 岡：慢性中耳㷋のオージオグラム，日耳.與，61.560， 1958. 3) 佐藤 (蜻雄)：鼓室小骨に関する研究 (第

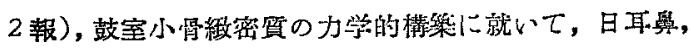

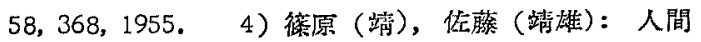

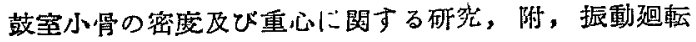
軸についての将察，日年算，59, 89, 1956. 5) Asherson, N.: The radical mastoid operation. A pre and post-operative audiometric statistical survey of hearing loss in chronic otorrhoea. J. Laryng. \& Otol. $62 ; 568,1948$. 6) 楠岡, 野田 : 中耳矤患の統計的観祭、特にその鼓膜等孔部位に就い $\tau$, 耳堠，23，215，1951，7）磯野：慢性中耳炎の成

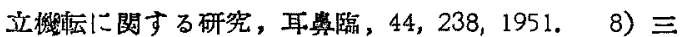

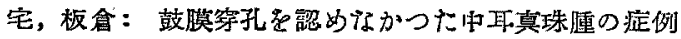

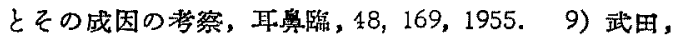

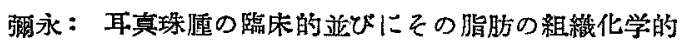

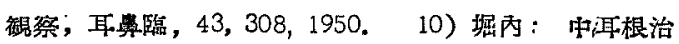
手法より得たる中耳炎族における小聴骨について，大 日耳, 41，1405，1935，11）後藤（修）：漫性中耳化 眐鿊における鐙骨の可動性, 耳喉, 27, 303, 1955.12 )

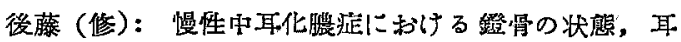
喉, 28, 159, 1956. 13) Meyer, E.: Das Gehör. Im. Handbuch der Physik. herausgeg. von $H$, Geiger. u. K, Scheel. Bd. 8 (Akustik), Berlin. 1927. 14) Derselbe: Experimentelle Trommelfellbelastung und Luftleitungsaudiogram mit allgemeinen Betrachtungen zur normalen und Pathologischenphysiologie des Schalleitungsapparates. Arch. Ohr-usw. heilk. 146, 372, 1935.

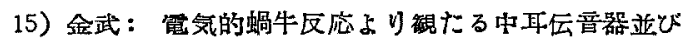

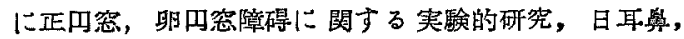
57, 33, 1954. 16) Maxwell, J.H. \& Richter, H.J.: Radicai Mastoidectomy. (its effect on hearing) A.MA. Arch. of Otol. 31;426, 1940. 17) 小琶:

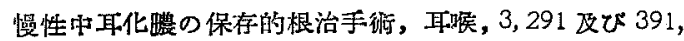
1930. 18) Politzer, A.: Lehrebuch der Ohrenheilkunde. Stuttgart. 1908. 19) 传藤 (恒)：伀豆

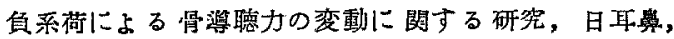
59,859，1956. 20）切替，北山：咡耳炎に後発せる

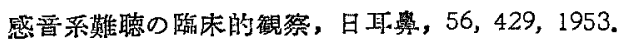

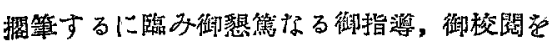
睗つた切替一郎教授に深謝する。また，年余に 没り本研觉に御助力頂いた传藤䠌雄悽士，椿茂 和学士，大和田一期学士に感謝する。なお㖕測 は古城塨哉膤士の御好意による所大であり，中 村蜸二博士よりは種々，有益圾る御助言艺頂い た・記して感謝の意を表する。

本研觉の裂旨は日本耳.舆咽喉科学会，関東地 方会第32 回大会において無䒾した。

（原稿到差 $=$ 炤和 32.10 .31 日） 